\title{
Different effectiveness of Helicobacter pylori lipopolysaccharides with or without LewisXY determinants in stimulating the secretion of proinflammatory cytokines IL-8 and TNF- $\alpha$ by peripheral blood mononuclear leukocytes
}

Odmienna skuteczność lipopolisacharydów Helicobacter pylori różniących się ekspresją determinantów antygenowych LewisXY w pobudzaniu leukocytów jednojądrzastych krwi obwodowej do wydzielania cytokin prozapalnych: IL-8 i TNF- $\alpha$

Karolina Rudnicka1 , Aneta Grębowska ${ }^{1}$, Anthony P. Moran², Agnieszka Matusiak ${ }^{1}$, Maria Walencka ${ }^{1}$, Eliza Miszczyk ${ }^{1}$, Leokadia Bąk-Romaniszyn ${ }^{3}$, Elżbieta Czkwianianc ${ }^{4}$, Izabela Płaneta-Małecka ${ }^{4}$, Wiesława Rudnicka1, Magdalena Chmiela ${ }^{1}$

1Department of Immunology and Infectious Biology, University of Lodz, Poland

2National University of Galway, Ireland

3Department of Paediatrics, Clinical Immunology, Polish Mother's Memorial Hospital, Lodz, Poland

${ }^{4}$ Department of Gastroenterology and Paediatrics, Polish Mother's Memorial Hospital, Lodz Poland

Przegląd Gastroenterologiczny 2011; 6 (6): 401-408 DOI: 10.5114/pg.2011.25996

Key words: Helicobacter pylori, lipopolysaccharides, interleukin 8, tumour necrosis factor $\alpha$.

Słowa kluczowe: Helicobacter pylori, lipopolisacharydy, interleukina 8, czynnik martwicy nowotworów $\alpha$.

Address for correspondence: Prof. Magdalena Mikołajczyk-Chmiela, Department of Immunology and Infectious Biology, University of Lodz, 12/16 Banacha, 90-237 Lodz, Poland, phone: +48 4263541 86, fax: +48 42665 58 18, e-mail: chmiela@biol.uni.lodz.pl

\begin{abstract}
Introduction: Helicobacter pylori is an aetiological agent of chronic gastritis, gastric and duodenal ulcers, and gastric cancers. It is suggested that $H$. pylori must have undergone evolutionary changes that enable the bacteria to overcome the host immune response. The molecular mimicry between Lewis (Le) determinants present in $\mathrm{H}$. pylori lipopolysaccharide (LPS) and on the host cells may play a role in the outcome of H. pylori infections.

Aim: In this study we investigated the production of inflammatory cytokines tumour necrosis factor $\alpha$ (TNF- $\alpha$ ) and interleukin 8 (IL-8), by human peripheral blood mononuclear leukocytes (PBML) from H. pylori infected (11) and uninfected (10) subjects (21 women, aged 25-50 years), in response to H. pylori-LPS with LeXY(+) or without LeXY(-) determinants. Material and methods: Peripheral blood was collected using the Vacutainer heparin system and constituted a source of total or monocyte and lymphocyte enriched PBML fractions. Tumour necrosis factor $\alpha$ and IL-8 were assessed by immunosorbent assay (ELISA) in the supernatants from
\end{abstract}

\section{Streszczenie}

Wstęp: Pałeczki Helicobacter pylori są przyczyną przewlekłego zapalenia błony śluzowej żołądka, owrzodzeń żołądka lub dwunastnicy oraz nowotworów żołądka. Prawdopodobnie bakterie te podlegały takim zmianom ewolucyjnym, które umożliwity im przystosowanie się do życia w organizmie gospodarza poprzez unikanie jego mechanizmów obronnych. Podobieństwo molekularne pomiędzy determinantami antygenowymi Lewis (Le) występującymi w lipopolisacharydzie (LPS) H. pylori oraz na komórkach gospodarza może odgrywać ważną rolę w procesach przystosowawczych tych bakterii. Cel: W pracy oceniono wytwarzanie cytokin prozapalnych: czynnika martwicy nowotworów $\alpha$ (TNF- $\alpha$ ) oraz interleukiny 8 (IL-8) przez leukocyty jednojądrzaste krwi obwodowej dawców (21 kobiet w wieku 25-50 lat), zakażonych (11) lub niezakażonych (10) H. pylori, w odpowiedzi na LPS H. pylori LeXY(+) lub LeXY(-).

Materiat i metody: Leukocyty krwi obwodowej otrzymane z wykorzystaniem heparynizowanego systemu Vacutainer stanowiły źródło pełnej zawiesiny leukocytów jednojądrza- 
leukocyte cultures stimulated or not with $H$. pylori LPS or standard Escherichia coli LPS.

Results: The results showed that adherent but not non-adherent PBML responded to $H$. pylori-LPS by TNF- $\alpha$ and IL- 8 production. The H. pylori-LPS LeXY(+) was a stronger stimulus for macrophage-derived cytokines, as compared with $\mathrm{H}$. pyloriLPS LeXY(-). Helicobacter pylori-LPS LeXY(+) driven production of TNF- $\alpha$ and IL- 8 was significantly inhibited with antibodies to LPS-binding protein (LBP) and to CD14 proteins.

Conclusions: It is possible that LeXY determinants of $\mathrm{H}$. pyloriLPS could be involved in LPS signalling for inflammatory cytokines and thus regulate the outcome of $H$. pylori infections.

\section{Introduction}

Helicobacter pylori has been recognized as a major causative agent of chronic gastritis, gastric and duodenal ulcers and gastric cancer [1]. However, its ability to cause chronic persistent colonization, growth and active adaptation to the acidic environment of the human stomach and resistance to the host defence mechanisms is still under discussion [2]. It is suggested that $H$. pylori bacteria must have undergone evolutionary changes that enable them to survive the host immune response. On the other hand, they must express highly diverse virulence factors contributing to the disease development $[3,4]$. However, not only bacterial but also host factors such as genetic predisposition play an important role in the development, maintenance and the outcome of the disease. Several functional polymorphisms have been described in the genes encoding cytokines and their receptors $[5,6]$. Experimental animal models have confirmed that the host response is an important determinant in the severity of gastritis [7]. Two systems of immune response, innate and acquired, are involved in the eradication of infectious agents. Innate immunity provides a rapid, unspecific host defence but is also necessary for the development of an acquired, specific response that should overcome the infection. In the early stages of infection, $H$. pylori lipopolysaccharide (LPS) activates the innate immune system and induces secretion of the chemotactic factors such as interleukin 8 (IL-8), as well as production of other proinflammatory cytokines including IL-1, IL-6 and tumour necrosis factor $\alpha$ (TNF- $\alpha)[8,9]$. These molecules are responsible for recruitment of inflammatory cells: neutrophils, monocytes, macrophages, mast cells, as well as lymphocytes $\mathrm{T}$ and $\mathrm{B}$.

It is suggested that $H$. pylori may use mechanisms similar to other pathogens or commensals to achieve stych (peripheral blood mononuclear leukocytes - PBML) oraz zawiesin wzbogaconych w monocyty lub limfocyty. Stężenie TNF- $\alpha$ i IL-8 w supernatantach z hodowli niestymulowanych lub stymulowanych LPS $H$. pylori LeXY(+) lub LeXY(-) oraz wzorcowym LPS Escherichia coli oceniano w immunoenzymatycznym teście ELISA.

Wyniki: Głównym źródłem TNF- $\alpha$ i IL-8, w odpowiedzi na LPS H. pylori, była frakcja PBML wzbogacona w monocyty. Wykazano, że LPS H. pylori LeXY(+) silniej stymulowat wytwarzanie obu cytokin pochodzenia makrofagowego niż LPS typu LeXY(-). Sekrecja TNF- $\alpha$ i IL-8 przez PBML stymulowane LPS $H$. pylori LeXY(+) była istotnie hamowana w środowisku przeciwciał przeciwko białkom LBP (białko wiążące LPS) i CD14.

Wnioski: Można przypuszczać, że determinanty antygenowe LeXY występujące w LPS H. pylori mogą modulować ścieżki sygnałowe cytokin prozapalnych i na tej drodze regulować przebieg takich zakażeń.

the suppression or evasion of the innate immune system $[10,11]$. Helicobacter pylori has developed the ability to vary its LPS chemistry and thereby subvert the recognition by innate immune receptors $[12,13]$. The majority of $H$. pylori strains express in their LPS the Lewis (Le) determinants (LeX, LeY, Le ${ }^{a}, L^{b}$ ) that are similar to the epitopes present on the gastric epithelial cells of the host [14]. Helicobacter pylori may modulate the expression of Lewis antigens in response to variable environmental conditions in the stomach. This may facilitate persistent colonization [15]. The increased adherence of $H$. pylori to the gastric mucosa enhances the interaction between the bacterial and the host cells, which is followed by activation of the nuclear factor $\kappa \mathrm{B}(\mathrm{NF}-\kappa \mathrm{B})$ transcription factor and the signal transduction pathway [16]. The phase-variable expression of Lewis antigens allows the bacteria to modulate the host adaptive immune response through interactions with DC-SIGN (Dendritic Cell-Specific Intercellular adhesion molecule3-Grabbing Nonintegrin) on dendritic cells and macrophage subpopulations [17]. Although it is known that macrophages are the main target of bacterial LPS, the interaction between $H$. pylori LPS (differing in the expression of Lewis determinants) and cells of the monocyte/macrophage lineage is poorly understood. We focused attention on a potential impact of such cells in the production of cytokines playing a crucial role in initiation of the immune response towards infectious agents.

\section{Aim}

The aim of this study was to evaluate the secretory activity of PBML isolated from $H$. pylori infected and uninfected donors, concerning IL- 8 and TNF- $\alpha$ production, in response to $H$. pylori LPS of LeXY(-) or LeXY(+) type. The non-separated PBML as well as monocyte or 
lymphocyte enriched PBML fractions were used as targets for $H$. pylori LPS. The monoclonal anti-CD14 and anti-LBP antibodies were used for assessment of the CD14-dependent signalling pathway for IL-8 and TNF- $\alpha$ secretion in response to $H$. pylori LPS.

\section{Material and methods Subjects}

Twenty-one healthy women (25-50 years old) participated in this study and signed their consent. The Local Ethical Committee approved the study protocol. The $H$. pylori status was assessed by ${ }^{13} \mathrm{C}$ urea breath test (UBT) [18] and anti-H. pylori antibody production detected in ELISA assay as previously described [19]. The volunteers were divided into two groups, one with UBT and anti-H. pylori IgG positive $-H$. pylori infected H.p. (+) and the other with UBT and anti-H. pylori IgG negative $-H$. pylori non-infected $-H$.p. $(-)$. They did not receive any antibiotics, bismuth salts, non-steroidal anti-inflammatory or immunosuppressive agents.

\section{Leukocyte cultures}

Peripheral blood was collected using the Vacutainer system with heparin as an anticoagulant factor. In the experiments, the samples of peripheral blood (30 ml) from 21 donors, $11 \mathrm{H}$. pylori positive H.p. (+) and $10 \mathrm{H}$. pylori negative H.p. (-) were separated by Lymphoprep-gradient centrifugation as recommended by the manufacturer (Nycomed Pharma AS, Norway) in order to obtain PBML. The total PBML population $\left(5 \times 10^{5}\right.$ in $100 \mu \mathrm{l} /$ well) in 96-well microplates was stimulated for $24 \mathrm{~h}\left(37^{\circ} \mathrm{C}, 5 \% \mathrm{CO}_{2}\right)$ in triplicate with $100 \mu \mathrm{l} /$ well of standard E. coli LPS (Sigma, St. Louis, Michigan, US) or with $H$. pylori LPS, with or without Lewis XY determinants $(200 \mathrm{ng} / \mathrm{ml})$. Spontaneous cytokine activity of the cells was assessed in the cultures in a complete medium without any stimulus. The experiments were performed in the RPMI-1640 medium containing $10 \%$ fetal calf serum (FCS), $200 \mathrm{mM}$ L-glutamine and $50 \mu \mathrm{g} / \mathrm{ml}$ gentamicin (complete medium). The $H$. pylori LPS was prepared by the hot phenol-water procedure after pre-treatment of bacterial biomass with protease. Then the LPS preparation was purified by RNase, DNase and proteinase $\mathrm{K}$ treatment and by ultracentrifugation, as previously described [12]. In some experiments the cell suspensions enriched with monocytes or lymphocytes were used. For this purpose, the total fraction of mononuclear leukocytes was incubated for $1 \mathrm{~h}\left(37^{\circ} \mathrm{C}, 5 \% \mathrm{CO}_{2}\right)$ in culture plates, to obtain the adherent and nonadherent cell fractions. The non-adherent cells were used for preparing the lymphocyte-enriched fraction, whereas the remaining adherent cells were a source of monocyte-enriched fraction. The role of CD14 receptor in cytokine signalling and secretion, in response to H. pylori LPS, was estimated using the cells pre-treated for $15 \min \left(37^{\circ} \mathrm{C}, 5 \% \mathrm{CO}_{2}\right)$, with mouse monoclonal antibodies against human CD14 and lipopolysaccharide binding protein (LBP) molecules (HyCult Biotechnology, Uden, The Netherlands) in a concentration of $10 \mu \mathrm{g} / \mathrm{ml}$ before stimulation with $H$. pylori LPS preparations.

After 24-h incubation of the cells, the cell culture supernatants were collected in order to estimate IL-8 and TNF- $\alpha$ concentration, centrifuged and frozen at $-20^{\circ} \mathrm{C}$ in $100 \mu \mathrm{l}$ aliquots.

\section{Assessment of cytokine secretion}

The cell culture supernatants were assayed to determine the level of IL- 8 and TNF- $\alpha$. The cytokine levels in the cell culture supernatants were measured by ELISA method using commercial assays (Qantikine ${ }^{\circledR}$ Human TNF- $\alpha$, Immunoassay and Qantikine ${ }^{\circledR}$ Human IL-8 Immunoassay (R\&D System, Minneapolis, USA), as recommended by the manufacturer.

In all experiments, the wells coated with antihuman IL-8 or anti-human TNF- $\alpha$ monoclonal mouse antibody were filled with the reagents for the control: known concentrations of recombinant human IL-8 (rhIL-8) or rhTNF- $\alpha$, anti-human IL-8 or with antihuman TNF- $\alpha$ polyclonal goat IgG antibody labelled with horseradish peroxidase (HRP), and with a chromogenic substrate, OPD, for development of a colour reaction. The absorbance values were measured in a Victor 2 counter (Wallac Oy, Turku, Finland) at $\lambda=450$ $\mathrm{nm}$ and $\lambda=490 \mathrm{~nm}$. Based on the absorbance values (A) for each rhIL-8 and rhTNF- $\alpha$ dilution, the standard curve was constructed on the basis of the equation for a straight line: $y=a x+b$. The parameters " $a$ " and " $b$ " were calculated from the slope and the $y$-intercept, respectively, of the drawn line. The concentrations of IL- 8 and TNF- $\alpha$ in the culture supernatants were estimated on the basis of the following formula: IL-8 $(\mathrm{ng} / \mathrm{ml})=A-b / a$ or TNF- $\alpha(\mathrm{pg} / \mathrm{ml})=A-b / a(A-$ absorbance, $a$ - the regression coefficient, $b$ - the point of the line's intersection with the Y-axis).

\section{Statistical analysis}

Statistica 5.5 PL software with non-parametric tests was used: Mann-Whitney $U$ test (for unpaired data) to verify the hypothesis that the two compared samples came from two statistically different populations; and $\chi^{2}$ test to compare the prevalence of the analysed parameters in the studied groups. 


\section{Results}

TNF- $\alpha$ and IL- 8 production by PBML from $H$. pylori infected and $H$. pylori uninfected individuals

Production of TNF- $\alpha$ and IL- 8 is pivotal in initiation of the immune response to pathogens. The contribution of TNF- $\alpha$ to improvement of the adhesive molecules' expression on the surface of endothelial cells and the role of IL-8 as a chemotactic factor for immunocompetent cells are well established. In this study, the levels of TNF- $\alpha$ and IL- 8 were estimated in culture supernatants of PBML from $H$. pylori infected or uninfected donors, stimulated with $H$. pylori LPS with or without Lewis XY determinants, and with the referent $E$. coli LPS. The levels of TNF- $\alpha$ and IL- 8 were estimated using the ELISA test. The sensitivity of the test was determined based on the analysis of the mean value of absorbance for controls and dilutions of the TNF- $\alpha$ and IL- 8 standards. All of the PBML from $H$. pylori (+) and $H$. pylori (-) volunteers produced TNF- $\alpha$ and IL-8 spontaneously as well as in response to $H$. pylori LPS with or without Lewis $X Y$ determinants, and to standard E. coli LPS.

The intensity of the TNF- $\alpha$ secretion varied between individuals. However, differences in the mean cytokine quantities were observed (Figure $1 \mathrm{~A}$ ). In both groups of donors the TNF- $\alpha$ production by PBML in response to $H$. pylori LPS of LeXY(-) type was very low, even slightly lower than in the milieu of culture medium alone. By comparison, the TNF- $\alpha$ production by PBML in response to $H$. pylori LPS of LeXY(+) type as well as to $E$. coli LPS was significantly higher as compared to the natural secretion level and to the response to $H$. pylori LPS of LeXY $(-)$ type $(p<0.05)$. However, there were no significant differences between the groups of $H$. pylori $(+)$ and $H$. pylori $(-)$, in the mean production of TNF- $\alpha$ by PBML stimulated with $H$. pylori LPS of Lewis $\mathrm{XY}(+)$ or Lewis $X Y(-)$ type, the LPS of $E$. coli or those unstimulated.

Figure $1 \mathrm{~B}$ shows the secretion of IL- 8 by PBML, unstimulated or stimulated with $H$. pylori or E. coli LPS, from the volunteers negative or positive for $H$. pylori infection. Similarly, the intensity of the secretion of IL-8 varied between the individuals. Among $\mathrm{H}$. pylori (+) donors the production of IL-8 by PBML unstimulated or stimulated with $H$. pylori LPS of LeXY(-) or LeXY(+) type as well as by $E$. coli LPS did not differ significantly. However, in the group of $H$. pylori (-) donors the mean secretion of IL-8 was significantly higher in response to H. pylori LPS of LeXY(+) type and to E. coli LPS, as compared to natural IL-8 production, and to the secretion of such cytokine in response to $H$. pylori LPS of LeXY(-) type. A comparative analysis of IL-8 secretion by PBML unstimulated or stimulated with $H$. pylori and E. coli LPS in the group of $H$. pylori infected or uninfected donors was performed. The mean intensity of IL-8 production by PBML from $H$. pylori $(-)$ donors was higher than the production of such cytokine by leukocytes from $H$. pylori (+) individuals when $H$. pylori LPS of LeXY(+) type and E. coli LPS were used for PBML stimulation. In the case of E. coli LPS the difference was statistically significant (Figure $1 \mathrm{~B}$ ).

In this study the $H$. pylori LPS of LeXY(+) type stimulated the PBML, in the group of $H$. pylori infected or uninfected donors, more effectively than $H$. pylori LPS of LeXY(-) type. To determine which leukocyte fraction produced TNF- $\alpha$ and IL-8 in response to $H$. pylori LPS of LeXY(+) type, the PBML from both groups of donors, H. pylori (+) and H. pylori (-) (which responded by production of both cytokines), were separated in order to prepare the monocyte or lymphocyte enriched cell suspensions. A clear distinction between monocytes and lymphocytes as regards the TNF- $\alpha$ and IL- 8 production in response to $H$. pylori LPS of LeXY(+) type was observed. The monocytes consisted of the main leukocyte fraction responding by TNF- $\alpha$ and IL- 8 production when stimulated with $H$. pylori LPS of LeXY(+) type (Figure 2).

Inhibition with monoclonal anti-CD14 and anti-LBP antibodies of TNF- $\alpha$ and IL-8 production by PBML from $H$. pylori infected or uninfected subjects, in response to $H$. pylori LPS

In order to know whether $H$. pylori LPS signalling for the production of two inflammatory cytokines, IL-8 and TNF- $\alpha$, involves the cell surface and soluble molecules, CD14 and LBP, respectively, the PBML cultures in the presence or absence of monoclonal anti-CD14 and anti-LBP antibodies were used for stimulation of the cells with $H$. pylori LPS of LeXY(+) type. Figure 3 shows the mean intensity of TNF- $\alpha$ (Figure 3 A) and IL-8 (Figure $3 \mathrm{~B}$ ) production in PBML cultures from three H. pylori (+) (D1-D3) and two H. pylori (-) (D4, D5) donors, with or without anti-CD14 and anti-LBP antibodies, in response to $H$. pylori LPS of LeXY(+) type. In all cases the TNF- $\alpha$ production was totally abolished in the milieu of anti-CD14 and anti-LBP antibodies. In two cases (donors D2, D3) the anti-CD14 antibody significantly decreased the production of TNF- $\alpha$ by PBML (Figure $3 \mathrm{~A}$ ). The IL-8 production by PBML cultures from four out of five donors was completely stopped with the anti-CD14 antibody (donors D2-D5) and with the anti-LBP antibody (donors D1, D2, D4, D5). Significant inhibition of IL-8 secretion was detected for PBML cultures from donor D1 after treatment of the cells with the anti-CD14 antibody, and for PBML cultures from donor D3 after pre-treatment of the cells with the antiLBP antibody (Figure $3 \mathrm{~B}$ ). 


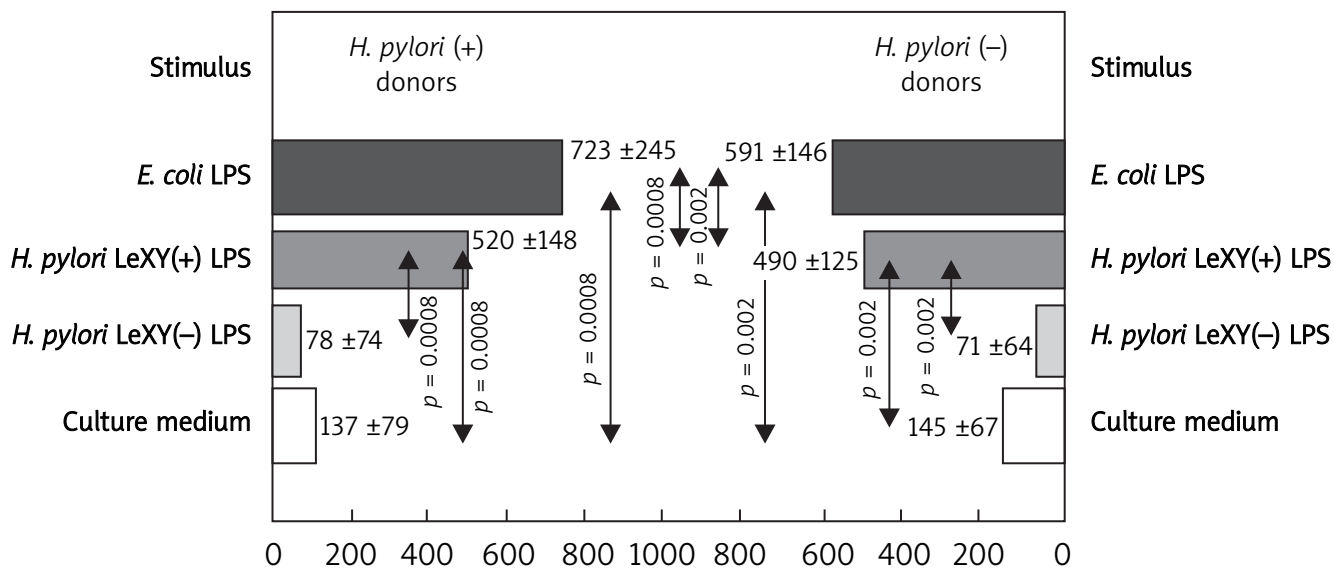

\section{IL-8 production by PBML}

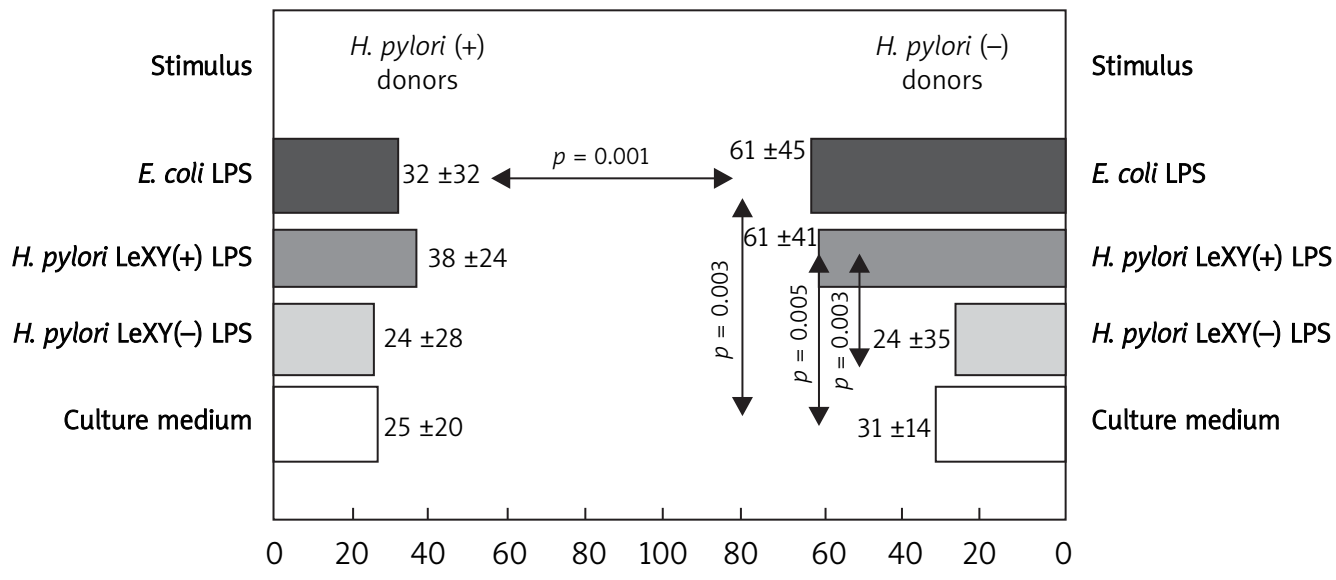

$\square$ Culture medium $\square$. pylori LeXY (-) LPS treated $\square$. pylori LeXY (+) LPS treated $\square$ E. coli LPS treated

Fig. 1. Comparison of TNF- $\alpha$ (A) and IL-8 (B) production by peripheral blood mononuclear leukocytes (PBML) from H. pylori infected (H. pylori (+)) and H. pylori uninfected (H. pylori $(-))$ donors, unstimulated (culture medium) or stimulated with H. pylori lipopolysaccharide (LPS) with (H. pylori LPS LeXY(+)) or without (H. pylori LPS LeXY(-)) Lewis determinants or with standard E. coli LPS

Ryc. 1. Porównanie wydzielania TNF- $\alpha$ (A) oraz IL-8 (B) przez leukocyty krwi obwodowej (PBML) dawców zakażonych (H. pylori (+)) lub niezakażonych (H. pylori (-)) pateczkami H. pylori, niestymulowane (podłoże hodowlane) lub stymulowane LPS H. pylori z determinantami antygenowymi Lewis (H. pylori LPS LeXY(+)) lub bez (H. pylori LPS Le XY(-))

\section{Discussion}

The majority of $H$. pylori-infected individuals are asymptomatic despite persistent chronic infection. The reason why some individuals remain $H$. pylori-infected for life but without any symptoms while others develop severe diseases is unknown, but presumably the discrepancy results from multifactorial interactions among host immunological and physiological factors, bacterial virulence determinants and several environmental influ- ences that modulate the host response. The balance of bacterial factors and host inflammatory response to H. pylori infection determines the disease outcome. Even in asymptomatic subjects, H. pylori induces histological gastritis, which is characterized by a dense infiltration of granulocytes, monocytes and lymphocytes in gastric mucosa. The production of inflammatory cytokines plays a primary role in $\mathrm{H}$. pylori-induced gastroduodenal diseases. Interleukin-8 has been shown to 


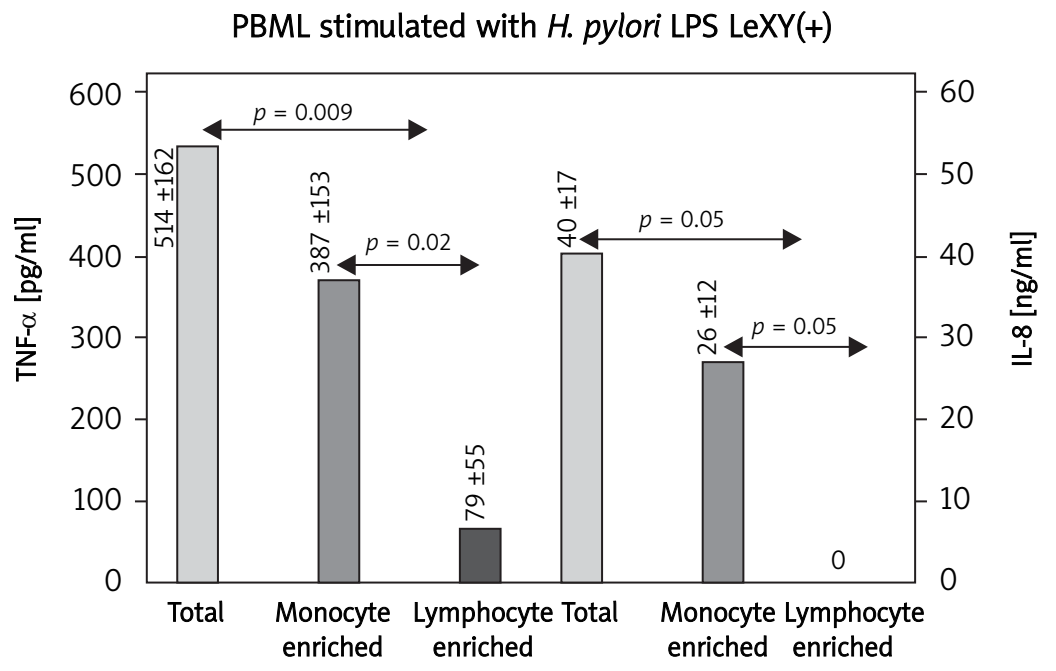

Fig. 2. Comparison of TNF- $\alpha$ and IL-8 production by non-separated peripheral blood mononuclear leukocytes (PBML) from selected donors, as well as by monocyte or lymphocyte enriched PBML fractions, in response to $H$. pylori lipopolysaccharide (LPS) of Lewis XY type [LeXY(+)]

Ryc. 2. Porównanie wytwarzania TNF- $\alpha$ i IL-8 przez komórki jednojądrzaste krwi obwodowej wybranych dawców, nierozdzielone lub wzbogacone $w$ monocyty lub limfocyty, $w$ odpowiedzi na lipopolisacharyd (LPS) H. pylori majacy determinanty antygenowe Lewis XY [LeXY(+)]

A

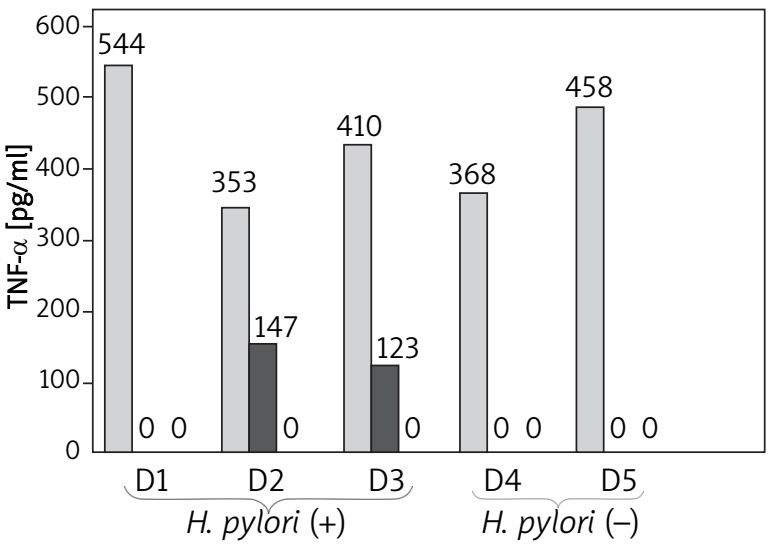

PBML donors
B

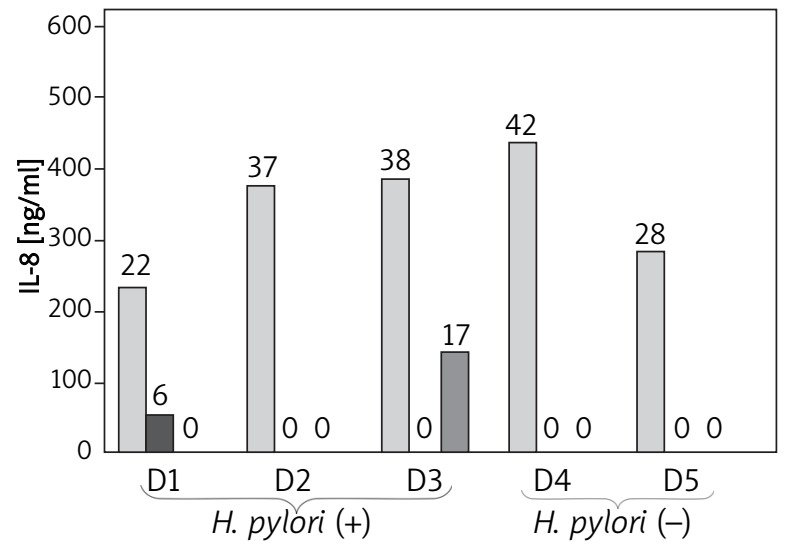

PBML donors

$\square$ Unreated PBML $\quad \square$ Anti-CD14 treated PBML $\square$ Anti-LBP treated PBML

Fig. 3. Inhibition of TNF- $\alpha$ (A) and IL-8 (B) production by peripheral blood mononuclear leukocytes (PBML) from selected donors, untreated or pre-incubated with monoclonal anti-CD14 and anti-LBP (LPS binding protein) antibodies in response to LPS with Lewis XY determinants [LeXY $(+)]$

Ryc. 3. Zahamowanie wytwarzania TNF- $\alpha$ (A) i IL-8 (B) przez leukocyty jednojądrzaste krwi obwodowej (PBML) wybranych dawców, nietraktowane lub traktowane przeciwciatami monoklonalnymi anty-LBP (biatko wiążace lipopolisacharyd - LPS) lub anty-CD14, w odpowiedzi na LPS H. pylori mający determinanty antygenowe Lewis $X Y[\operatorname{LeXY}(+)]$ 
play a key role in this event. Direct contact of whole bacteria with epithelial cells might be critical for IL-8 induction in vivo [20]. The ability of $H$. pylori strains to induce IL-8 secretion from $H$. pylori-activated gastric epithelial cells and neutrophils seems to be associated with the expression of cagA (cytotoxicity associated gene A) and other genes within the pathogenicity island [21]. $H$. pylori infections are also associated with local increase in IL-1 $\beta, \mathrm{IL}-6$ and TNF- $\alpha$ and there is a correlation between the overproduction of these cytokines and a high-grade mucosal inflammation [22].

Helicobacter pylori is a genetically diverse species [23]. The strains isolated from different hosts present various virulence capacity. The bacteria containing cagPAI more frequently induce severe gastritis, gastric ulcer, atrophic gastritis and gastric cancer [24]. Helicobacter pylori isolated from one individual may express LeX or LeY or both determinants, suggesting a population of clone variants colonizing gastric mucosa [12]. It has been suggested that the release of LPS from $H$. pylori in the site of the infectious niche may play an important role in inducing a local or systemic inflammatory response. In this study we asked whether LeX and LeY determinants of $H$. pylori LPS may influence the production of inflammatory cytokines such as TNF- $\alpha$ and IL-8. We showed that the lack of Lewis determinants in $H$. pylori LPS resulted in a significant reduction of its ability to induce TNF- $\alpha$ secretion by peripheral blood mononuclear leukocyte cultures as compared to the activity of H. pylori LPS containing LeXY determinants as well as to the activity of standard E. coli LPS. A similar tendency has been shown for IL-8 secretion but only concerning PBML from $H$. pylori negative donors. This may confirm that both bacterial and host factors might be important for the development and maintenance of the inflammatory response during $H$. pylori infections. Tumour necrosis factor $\alpha$ and IL- 8 were produced mainly by monocyte-enriched fraction of PBMC, in response to $H$. pylori LPS of LeXY type. Two LPS binding sites were needed for TNF- $\alpha$ and IL- 8 production, which was shown by inhibition of these cytokines' secretion in PBML cultures pretreated with monoclonal anti-LBP and anti-CD14 antibodies before stimulation of PBML with $H$. pylori LPS of LeXY type, as compared to antibody untreated cells. The role of LeXY determinants of $H$. pylori LPS during the course of $H$. pylori infections remains unclear. It has been suggested that the host Lewis phenotype may select $H$. pylori expressing Lewis antigens based on the similarities between LeX and Le ${ }^{a}$ or LeY and Le $e^{b}$ determinants [25].

It has also been shown that $H$. pylori LPS diminished ingestion of $H$. pylori by human polymorphonuclear leukocytes (PMNs) [26]. Lipopolisacharides driven inhibi- tion of $H$. pylori ingestion by PMNs was neutralized by recombinant LPS-binding protein (LBP), but it was Lewis antigen independent although LBP was found to interact in the ELISA assay with H. pylori LPSs with LeX or LeXY but not with LPS lacking Lewis determinants. Thus, LPS/LBP binding could be significant for activation of PMNs via CD14 receptors resulting in the release of inflammatory cytokines rather than phagocytosis of the bacteria [26]. It is not possible to exclude a possibility that such phenomena could prevent the eradication of $H$. pylori bacteria and increase the inflammation that is providing bacteria with nutritive compounds. The $H$. pylori LPS has a much lower endotoxic activity, and also a lower ability to stimulate macrophages to produce proinflammatory cytokines, nitric oxide prostaglandins as compared to E. coli LPS. The low biological activity of $H$. pylori LPS is related to the modification of lipid A, which is the only region of LPS to be recognized by the innate system via the LPS receptor - the TLR4-MD2CD14 complex, which is present on macrophages, granulocytes and dendritic cells [27]. It has also been shown that $H$. pylori LPS induces cell activation rather through TLR2 but not TLR4 receptor and that LPS from some H. pylori strains may antagonize TLR4 [28]. However, in the light of the presented results, the influence of LeX and LeY determinants expressed in $H$. pylori LPS on the production of inflammatory cytokines by the host cells cannot be excluded. Recently, Grebowska et al. [29] have shown that both in patients with coronary heart syndrome (CAD) and in healthy subjects infected with $H$. pylori, the level of antibodies to LPS of LeXY(+) type was higher than to LPS of LeX(+) or LeXY(-) type, thus indicating that LPS of LeXY(+) type was most effective in the stimulation of humoral response, potentially selfdestructive, in the CAD H. pylori positive patients. Variations in $H$. pylori LPS may facilitate the bacteria to evade the innate immune component surfactant protein $D$. This phenomenon is linked to changes in the fucosylation of the $O$ chain, which was concomitant with slipped-strand mispairing in a poly (C) tract of the fucosyltransferase A (fuc T1) gene [13]. It has been suggested that $H$. pylori employs similar mechanisms compared to other pathogens or commensals to achieve evasion or suppression of the innate immune system including an increase or inhibition of responses [30]. Helicobacter pylori, similarly to many intestinal colonizers, developed mechanisms to vary its LPS chemistry in order to subvert the recognition by innate immune receptors [11].

In conclusion, we have demonstrated that $H$. pylori LPS, especially of the Lewis $X Y(+)$ type in vivo, might be involved in LPS signalling for inflammatory cytokines and in this way regulate the outcome of $H$. pylori infections and bacterial load. 


\section{Acknowledgments}

This study was financially supported by the Polish Ministry of Science and Higher Education (grant N N401 015 136).

\section{References}

1. Warren JM, Marshall BJ. Unidentified curved bacilli on the gastric epithelium in active chronic gastritis. Lancet 1983; 1: 1273-5.

2. Pflock M, Kennard S, Finsterer N, et al. Acid-responsive gene regulation in the human pathogen Helicobacter pylori. J Biotechnol 2006; 126: 52-60.

3. Mahdavi J, Sonden B, Hurtig M, et al. Helicobacter pylori SabA adhesion in persistent infection and chronic inflammation. Science 2002; 297: 573-8.

4. Wu AM, Crabtree JE, Bernstein L, et al. Role of Helicobacter pylori CagA+ strains and risk of adenocarcinoma of the stomach and esophagus. Int J Cancer 2003; 103: 815-21.

5. El-Omar EM, Carrington M, Chow W, et al. Interleukin 1 polymorphisms associated with increased risk of gastric cancer Nature 2000; 404: 398-402.

6. Kunstmann E, Epplen C, Elitok E, et al. Helicobacter pylori infection and polymorphisms in the tumor necrosis factor region. Electrophoresis 1999; 20: 1756-61.

7. Sakagami T, Dixon M, Orourke J, et at. Atrophic gastric changes in both Helicobacter felis and Helicobacter pylori infected mice are host dependent and separate from antral gastritis. Gut 1996; 39: 639-48.

8. Gianchetti P, Vaira D, Campieri M, et al. Enhanced mucosal interleukin-6 and -8 in Helicobacter pylori positive dyspeptic patients. Am J Gastroenterol 1994; 89: 883-7.

9. Noach L, Bosma NB, Jansen J, et al. Mucosal tumor necrosis factor-alpha, interleukin-1beta and interleukin-8 production in patients with Helicobacter pylori infection. Scand J Gastroenterol 1994; 29: 425-9.

10. Portnoy DA. Manipulation of innate immunity by bacterial pathogens. Curr Opin Immunol 2005; 17: 25-8.

11. Miller SI, Ernst RK, Bader MW, et al. LPS, TLR4 and infectious disease diversity. Nat Rev Microbiol 2005; 3: 36-46.

12. Monteiro MA, Appelmelk BJ, Rasko DA, et al. Lipopolysaccharide structures of Helicobacter pylori genomic strains 26695 and J99, mouse model H. pylori Sydney strain, H. pylori P466 carrying sialyl LewisX and $H$. pylori UA915 expressing LewisB. Classification of $H$. pylori lipopolysaccharides into glycotype families. Eur J Biochem 2000; 267: 305-20.

13. Khamri W, Moran AP, Worku ML, et al. Variations in Helicobacter pylori lipopolysaccharide to evade the innate immune component surfactant protein D. Infect Immun 2005; 73: 7677-86.

14. Moran AP, Knirel YA, Senchenkova SN, et al. Phenotypic variation in molecular mimicry between Helicobacter pylori lipopolysaccharides and human gastric epithelial cell surface glycoforms. Acid-induced phase variation in Lewis (x) and Lewis (y) expression by H. pylori lipopolysaccharides. J Biol Chem 2002; 277: 5785-95.

15. Skoglund A, Backhed HK, Nilsson CH, et al. A changing gastric environment leads to adaptation of lipopolysaccharide variants in Helicobacter pylori populations during colonization. PLoS 2009; 4: e5885.
16. Munzenmaier A, Lange C, Glocher E, et al. A secreted, shed product of Helicobacter pylori activates transcription factor nuclear factor-kappaB. J Immunol 1997; 159: 6140-7.

17. Bergman MP, Engering A, Amits $\mathrm{HH}$, et al. Helicobacter pylori modulates the $T$ helper cell $1 / T$ helper cell 2 balance through phase-variable interaction between lipopolysaccharide and DCSIGN. J Exp Med 2004; 200: 979-90.

18. Bielański W, Konturek SJ. New approach to $13 \mathrm{C}$ urea breath test capsule-based modification with low dose of $13 \mathrm{C}$ urea in the diagnosis of Helicobacter pylori infection. J Physiol Pharmacol 1996; 47: 545-53.

19. Rechciński T, Chmiela M, Małecka-Panas E, et al. Serological indicators of Helicobacter pylori infections in adult dyspeptic patients and healthy blood donors. Microbiol Immunol 1997; 41: 387-93.

20. Rieder G, Hatz RA, Moran AP, et al. Role of adherence in Interleukin-8 induction in Helicobacter pylori associated gastritis. Infect Immun 1997; 65: 3622-30.

21. Shimuyama T, Fukuda S, Liu Q, et al. Helicobacter pylori water soluble surface proteins prime human neutrophils for enhanced production of reactive oxygen species and stimulate chemokine production. J Clin Pathol 2003; 56: 348-51.

22. Ando T, Goto Y, Ishigurob K, et al. The interaction of host genetic factors and Helicobacter pylori infection. Inflammopharmacology 2007; 15: 10-4.

23. Blaser M, Berg D. Helicobacter pylori genetic diversity and risk of human disease. J Clin Invest 2001; 107: 767-73.

24. Israel DA, Salama N, Arnold CN, et al. Helicobacter pylori genetic diversity within the gastric niche of single human host. J Clin Invest 2001; 107: 611-20.

25. Blaser MJ. Helicobacter pylori balance and imbalance. J Gastroenterol Hepatol 1998; 10 (Suppl. 1): S15-8.

26. Grebowska A, Moran AP, Matusiak A, et al. Anti-phagocytic activity of Helicobacter pylori lipopolysaccharide (LPS) - possible modulation of the innate immune response to these bacteria. Pol J Microbiol 2008; 57: 195-92.

27. Moran AP, Aspinall GO. Unique structural and biologic features of Helicobacter pylori lipopolysaccharides. Prog Clin Biol Res 1998; 397: 37-49.

28. Lepper PM, Triantafilou M, Schumann C, et al. Lipopolysaccharides from Helicobacter pylori can act as antagonists for Tolllike receptor 4. Cell Microbiol 2005; 7: 519-28.

29. Grebowska A, Rechcinski T, Moran A, et al. Increased levels of immunoglobulin and non-immunoglobulin markers of host response to $H$. pylori LPS in the patients with coronary artery disease (CAD). Current Trends in Immunol 2006; 7: 85-96.

30. Cross ML. Microbes versus microbes: immune signals generated by probiotic lactobacilli and their role in protection against microbial pathogens. FEMS Immunol Med Microbiol 2002; 34: 245-53. 